Research Article

\title{
The Drainage Horizon Determination of High Directional Long Borehole and Gas Control Effect Analysis
}

\author{
Yuqi Shang (D), Guiyi Wu (D), Qinzhi Liu (D), Dezhong Kong ${ }^{(D)}$, and Qiang Li $(\mathbb{D}$ \\ College of Mining, Guizhou University, Guizhou, Guiyang 550025, China \\ Correspondence should be addressed to Qinzhi Liu; 39850741@qq.com and Dezhong Kong; dzkong@gzu.edu.cn
}

Received 30 May 2021; Revised 23 July 2021; Accepted 6 August 2021; Published 18 August 2021

Academic Editor: Zaobao Liu

Copyright (c) 2021 Yuqi Shang et al. This is an open access article distributed under the Creative Commons Attribution License, which permits unrestricted use, distribution, and reproduction in any medium, provided the original work is properly cited.

In order to effectively solve the problem of gas concentration overrun in the upper corner of goaf and tailentry during the mining of panel 9303 in Anshun Coal Mine, based on the advantages of controllable trajectory and wide coverage area of directional drilling technology, high directional long boreholes are arranged in tailentry 9303 to extract pressure relief gas. Firstly, the principle of high directional long borehole drainage technology is introduced, and the fracture evolution of overlying strata is obtained through using numerical simulation, theoretical calculation, and field practice, and the fracture evolution range is determined to be 6-12.69 m, and rationality of fracture height obtained by theoretical analysis and numerical simulation is verified by the method of field borehole peep observation. Through the analysis, it is concluded that the best location of the final hole is within the range of 6-12.69 $\mathrm{m}$ of the roof of coal seam 9\#. The field practice has proved that the final hole position of the high directional long borehole is arranged at $12 \mathrm{~m}$ from the roof of coal seam 9\#, and the average gas extraction concentration can reach $40 \%-50 \%$ after the borehole enters the stable extraction stage, the purity of gas extraction is up to $8.5 \mathrm{~m}^{3} / \mathrm{min}$, and the gas concentration in the upper corner of panel 9303 is stable below $0.5 \%$ during mining, which achieves good gas drainage and control effect and provides a new way for gas control under similar geological conditions.

\section{Introduction}

The coal resource in Guizhou Province is very abundant, known as "Jiangnan Coal Sea." The coal industry is one of the pillar industries in Guizhou Province, but coal seam gas content is generally high in Guizhou Province; coal and gas outburst disasters are serious. In particular, the number of coal layers is large, and the coal seam spacing is close, when the coal seam is mined, the pressure relief gas in the adjacent coal seam is easy to flow into the goaf of the working face through the delamination fracture and broken fracture. With the improvement and popularization of directional drilling technology and equipment in China, the use of high directional long boreholes technology to control coal mine gas problems is widely used in major coal mines.

Coal seam mining causes the redistribution of stress field of overlying strata $[1,2]$, resulting in deformation and failure of overlying strata, thus forming mining-induced fractures. Therefore, study on fracture evolution law of overlying strata on working face is very important to improve gas control ability of high-level directional long borehole technology. To determine the drainage horizon of efficient extraction of high directional long borehole, many studies have analyzed the fracture evolution law of overlying strata in goaf during coal mining. Wang and Mang [3] proposed the gas control mode of goaf by roof directional long borehole instead of high drainage roadway, and it is concluded that compared with the high drainage roadway, the roof directional long drilling can not only achieve the same treatment effect, but also greatly reduce the capital investment and shorten the construction period. Finally, the best drainage position is determined by FLAC ${ }^{3 \mathrm{D}}$ numerical simulation. Xu et al. [4] on the basis of predecessors, according to the actual working face roof overlying strata characteristics and mining conditions, the establishment of coal mining numerical simulation model, not only according to the results of numerical simulation and theoretical analysis to determine the high directional long drilling layout horizon, but also optimize 
the drilling structure, effectively reduces the gas concentration of the working face. Using the different-source prediction method, Cai et al. [5] analyzed gas emission source of working face, and the height range of caving zone and fracture zone in goaf is calculated theoretically, after the reasonable high drilling parameters are determined according to the specific situation of the mine. It was found that using roof strike high borehole gas drainage technology can effectively ensure the safe mining of working face. With the deepening of research on the overlying strata of working face, Cheng et al. [6] according to the simulation results of crack field, stress field, and strain field distribution, the range of fracture strengthening zone and compaction zone of goaf roof along the advancing direction of working face are divided. In their study, the borehole part in the fracture strengthening zone is the effective extraction area of boreholes; the length of the effective extraction section of boreholes and the development degree of fractures in the effective extraction section of boreholes jointly determine the extraction efficiency of long boreholes with high strike, revealing the mechanism of gas extraction by long boreholes with high strike in goaf roof. Li and Jin [7] simulate the mining process of panel 3304 in Zaozhuang Coal Mine by UDEC numerical simulation software, and combined with the theoretical analysis of rock fracture, according to the failure characteristics of coal seam roof and the change rule of displacement field in the simulation results, the maximum height position of roof rock caving zone and water flowing fault zone caused by mining is determined. The results show that the results obtained by field test are close to the numerical simulation results.

The above research, whether numerical simulation or model test, has carried on the beneficial exploration and the research to the goaf overburden law according to the different actual working condition and the geological condition [8] and has obtained the massive research results. Therefore, on the basis of previous studies, this paper adopts the method of combining numerical simulation, field test, and theoretical analysis to calculate and analyze the distribution range of caving zone and fracture zone, so as to determine the location of holes. Finally, the effect of gas drainage is investigated through field practice to verify the distribution range of fracture zone, and the directional drilling technology is used to accurately control the drilling trajectory, so that the drilling trajectory is always in the fracture zone, so as to intercept and extract the pressure relief gas in the adjacent layer and control the gas in the upper corner of the goaf to achieve the purpose of safe production.

\section{Engineering Background}

The panel 9303 of the Anshun Coal Mine has a buried depth of $398 \mathrm{~m}$ and belongs to a high gas mine. The dip angle of the coal seam is near horizontal, which are $8 \#, 9 \#$, and $10 \#$ coal seams (as shown in Figure 1), respectively. The coal seam 8\# and coal seam $10 \#$ are thin and therefore not mined. The mining coal seam 9\# is $12.44-12.94 \mathrm{~m}$ below the 10 \# coal seam and $14-16.55 \mathrm{~m}$ above the coal seam $8 \#$. The coal seam spacing is relatively close, so it is easy to cause disturbance to the adjacent coal seam due to the excavation of the working face, making the pressure relief gas flows to the working face through the cracks. The panel 9303 adopts the U-type ventilation mode. The goaf is easy to accumulate gas, and there is a risk of exceeding the gas volume fraction in the upper corner.

The panel 9303 is located in coal seam 9\# of 3rd panel, the panel length is $726 \mathrm{~m}$, and the setup entry length is $173 \mathrm{~m}$. The thickness of coal seam $9 \#$ is $1.52 \mathrm{~m}$, and the recoverable reserves of panel 9303 are 290.3 million tons. Coal seam 9\# roof is no false roof and direct top of silty mudstone, thickness $5.96 \mathrm{~m}$. The basic roof is limestone with a thickness of $4.79 \mathrm{~m}$. The direct bottom is fine sandstone with a thickness of $3.78 \mathrm{~m}$. The old base is siltstone with a thickness of $8.12 \mathrm{~m}$. The distance between coal seam 9\# and coal seam $8 \#$ is about $15 \mathrm{~m}$. The coal thickness of coal seam $8 \#$ is $0.2-0.58 \mathrm{~m}$, and the average coal thickness is $0.43 \mathrm{~m}$. The maximum gas content of coal seam $8 \#$ is $20.83 \mathrm{~m}^{3} / \mathrm{t}$.

\section{Drainage Position Determination}

3.1. Principle of Gas Drainage Technology with High Directional Long Borehole. Directional drilling technology and equipment reflect the most advanced level of underground drilling in coal mines at this stage $[9,10]$. Directional drilling is a kind of drilling method which uses natural bending law of drilling hole or artificial deflecting tool to extend drilling hole to predetermined target according to design requirement $[11,12]$.

The principle of gas drainage by high directional drilling is based on the "three zones" distribution theory and "O" circle theory of overlying strata. When overlying strata move and destroy on the working face, "falling zone, fracture zone, and bending subsidence zone" are formed in the vertical direction, namely, "vertical three zones." "Coal wall support influence zone, separation zone, and recompaction zone" are formed in the horizontal direction, namely, "transverse three zones" $[13,14]$. The separation zone is the mining fracture "O" circle. The "O" circle and the middle and lower parts of the fault zone are the main channels of gas migration and the main places for gas accumulation [15].

The horizon determination of high directional long borehole is crucial, which is directly related to the gas drainage effect, based on the distribution of the fracture zone of the overlying strata and "O" circle theory. On the one hand, the high directional long borehole cannot be arranged in the falling zone; otherwise, the rock crushing and caving will directly destroy the borehole, resulting in difficult drainage and even unable to extract. On the other hand, it cannot be arranged in the bending subsidence zone, because of the fracture development is poor in this zone, there is no effective gas flow channel between cracks, and the effect of gas extraction is poor. The best high directional long borehole arrangement horizon is the range of fracture zone in "three zones," because of the development of fractures in this zone, fractures are connected to each other to form an effective channel for gas flow, and will not cause serious damage to boreholes, which is conducive to gas extraction [16]. However, due to the different geological 


\begin{tabular}{|c|c|c|c|}
\hline Column & Name of rock & Thickness (m) & Lithologic character \\
\hline & Sandstone & 12.50 & $\begin{array}{l}\text { Pale grayish white, containing carbonated plant debris, in obvious } \\
\text { contact with sublayers }\end{array}$ \\
\hline & Fine sandstone & 7.99 & Pale gray white, mainly composed of quartz. \\
\hline & Siltstone & 16.88 & $\begin{array}{l}\text { Light gray to gray, with horizontal stratification, slightly } \\
\text { oblique stratification. }\end{array}$ \\
\hline & Mudstone & 14.73 & $\begin{array}{l}\text { Light gray, with horizontal bedding, loose and fragile, } \\
\text { good water absorption }\end{array}$ \\
\hline & 8\# Coal seam & 0.43 & Black powder, good coal quality, containing plant fossils \\
\hline & Siltstone & 4.26 & Dark gray, silty structure, dense and brittle. \\
\hline & limestone & 4.79 & Gray limestone containing chert nodules. \\
\hline & Silty mudstone & 5.96 & $\begin{array}{l}\text { Page-like or lamellar bedding,easy to crack into fragments when hit } \\
\text { with hard objects, poor water permeability. }\end{array}$ \\
\hline & $\begin{array}{c}9 \# \\
\text { Coal seam } \\
\end{array}$ & 1.5 & $\begin{array}{l}\text { Dark gray } \sim \text { gray, clumpy, patchy, containing fossil plant } \\
\text { roots, strong water absorption, easy to weathering. }\end{array}$ \\
\hline & Fine sandstone & 4.56 & $\begin{array}{l}\text { Pale gray white, mainly composed of quartz, containing plant } \\
\text { carbonized debris, and the underlying layer obviously contact. }\end{array}$ \\
\hline & Siltstone & 8.62 & Dark gray, silty structure, dense and brittle. \\
\hline & 10\# Coal seam & 0.49 & Black powder, good coal, contains plant fossils \\
\hline $\begin{array}{l}------ \\
------ \\
------\end{array}$ & $\begin{array}{l}\text { Medium } \\
\text { sandstone }\end{array}$ & 19.84 & $\begin{array}{l}\text { Dark gray gray, clumpy, patchy, containing fossil plant } \\
\text { roots, strong water absorption, easy to weathering. }\end{array}$ \\
\hline
\end{tabular}

FIgURE 1: Coal and rock strata histogram.

and mining conditions of working faces in different mining areas, the height of the "three zones" formed by the collapse of the overlying strata is also different. Therefore, in order to reasonably determine the high directional long boreholes arrangement horizon, it is necessary to determine the caving characteristics of overlying strata, the evolution of fractures, and the height of "three zones" of overlying strata.

3.2. Theoretical Calculation of "Three Zones" Height of Overlying Strata. The height of overlying strata falling zone and fracture zone is determined by the mining height of working face, coal seam dip angle, roof management method, roof lithology, and other factors. Considering the actual situation of working face, since the roof of coal seam $9 \#$ is silty mudstone, it belongs to soft rock. So, the following empirical formula is selected to calculate the height of falling zone and fracture zone $[17,18]$ :

$$
\begin{aligned}
& H_{1}=\frac{100 M}{6.2 M+10.0} \pm 2.5 \\
& H_{2}=\frac{100 M}{3.1 M+6.0} \pm 6.5 .
\end{aligned}
$$

In the formula, $H_{1}$ is the falling zone height. $H_{2}$ is the fracture zone height. $M$ is the thickness of coal seam mining; take the average thickness of $1.5 \mathrm{~m}$ into formulas (1) and (2), the height of falling zone $H_{1}$ is $5.27-10.27 \mathrm{~m}$, and the height of fracture zone $\mathrm{H}_{2}$ is $7.58-20.58 \mathrm{~m}$.
3.3. Numerical Simulation of Roof Crack Evolution in Goaf during Mining. In order to further accurately determine the fracture development characteristics of pamel 9303 under different advancing distances, based on the coal and rock strata histogram, physical and mechanical properties of coal strata, and panel 9303 mining conditions, the UDEC numerical simulation method is used to establish the evolution model of overlying strata fracture in the process of coal seam mining, so as to study the evolution characteristics of overlying strata fracture under different advancing distances and finally determine the most efficient hole arrangement horizon.

3.3.1. Establishment of Numerical Simulation Model. By cutting the blocks, UDEC separates the deformed materials into discrete block sets to represent the discontinuous medium. The block in the model uses the Mohr-Coulomb criterion to describe the deformation and failure process of rock materials [19], as shown in the following formula:

$$
R=c \cdot \cos \varphi+\frac{1}{2}\left(\sigma_{1}+\sigma_{3}\right) \cdot \sin \varphi .
$$

In the formula, $\varphi$ is the angle of internal friction of rock, $c$ is rock cohesion, $\sigma_{1}$ is the maximum principal stress, $\sigma_{3}$ is the minimum principal stress, and $R$ is the radius of stress circle, $R=\left(\sigma_{1}-\sigma_{3}\right) / 2$. And according to the geological prospecting report of Anshun Coal Mine, the mechanical parameters of the roof-floor of coal seam 9\# are obtained, as shown in Table 1. 
TABLE 1: The mechanical parameters of major rock mass for roof and floor.

\begin{tabular}{|c|c|c|c|c|c|c|}
\hline Name of rock & Density $\left(\mathrm{kg} \cdot \mathrm{m}^{-3}\right)$ & Bulk modulus (GPa) & $\begin{array}{c}\text { Shear } \\
\text { modulus (GPa) }\end{array}$ & $\begin{array}{c}\text { Cohesion } \\
\text { (MPa) }\end{array}$ & $\begin{array}{l}\text { Angle of internal } \\
\text { friction }\left({ }^{\circ}\right)\end{array}$ & Tensile strength $(\mathrm{MPa})$ \\
\hline Sandstone & 2600 & 5.27 & 11 & 2.3 & 39 & 4.35 \\
\hline Fine sandstone & 2645 & 4.62 & 18 & 8.36 & 34 & 2.35 \\
\hline Siltstone & 2700 & 5.6 & 7 & 5.3 & 35 & 2.86 \\
\hline Mudstone & 2550 & 4.16 & 4.69 & 1.41 & 37 & 3.2 \\
\hline Coal seam 8\# & 1350 & 3.95 & 2.2 & 2 & 30 & 1.04 \\
\hline Siltstone & 2700 & 5.6 & 3.8 & 5.3 & 35 & 2.86 \\
\hline Limestone & 2540 & 6.85 & 1.47 & 1.26 & 10 & 1.2 \\
\hline Silty mudstone & 2132 & 6 & 8.13 & 8.87 & 42 & 4.56 \\
\hline Limestone & 2540 & 6.85 & 1.47 & 1.26 & 10 & 1.2 \\
\hline Silty mudstone & 2132 & 6 & 8.13 & 8.87 & 42 & 4.56 \\
\hline Coal seam 9\# & 1300 & 4.33 & 5.1 & 2 & 38 & 1.04 \\
\hline Fine sandstone & 2245 & 24.62 & 12 & 6.36 & 34 & 2.35 \\
\hline Siltstone & 2100 & 5.6 & 7 & 5.3 & 35 & 2.86 \\
\hline Coal seam $10 \#$ & 1350 & 3.95 & 2.2 & 2 & 30 & 1.04 \\
\hline Medium sandstone & 2132 & 26 & 8.13 & 11.87 & 42 & 4.56 \\
\hline
\end{tabular}

Based on this, establish a simplified two-dimensional model by UDEC. The model is $200 \mathrm{~m}$ in length and $120 \mathrm{~m}$ in height. Displacement constraints are applied to the vertical direction and lower boundary of the model, and equivalent stress loads are applied to the upper boundary. According to the calculation, the equivalent load is $7.11 \mathrm{MPa}$. The advance length of the model is $120 \mathrm{~m}$ for excavation, and the development law of rock strata caving cracks is simulated. $40 \mathrm{~m}$ is left at both ends to offset the boundary effect (as shown in Figure 2).

3.3.2. Analysis of Roof Fracture Development. In the process of working face advancing, due to the influence of excavation work, the stress field is redistributed, resulting in the continuous evolution of mining cracks with excavation work [20-23]. Due to the supporting effect of coal wall at both ends of working face and the different lithology of rock strata, the collapse and subsidence degree of each rock strata are different, so the separation of rock strata will occur first; thus, the separation cracks will appear first. In general, the gas flow and concentration in borehole extraction will be significantly higher than before after the emergence of separation cracks. With the further excavation of the working face, after the large-scale collapse of the overlying strata, the fracture cracks are formed at both ends of the open cut hole and the working face. With the further increase of the excavation distance, the cracks in the upper central area of the goaf are gradually compacted, and the separation cracks begin to evolve upward. These fractures are interconnected and gradually form fracture channels, resulting in the continuous inflow of free gas from the adjacent layer and surrounding rock into the goaf through this channel, resulting in the gas concentration overrun in the working face.

In order to analyze and study the overlying strata fracture evolution law, the fracture evolution diagram of working face advancing to $30 \mathrm{~m}, 50 \mathrm{~m}, 80 \mathrm{~m}$, and $110 \mathrm{~m}$ is selected for analysis.

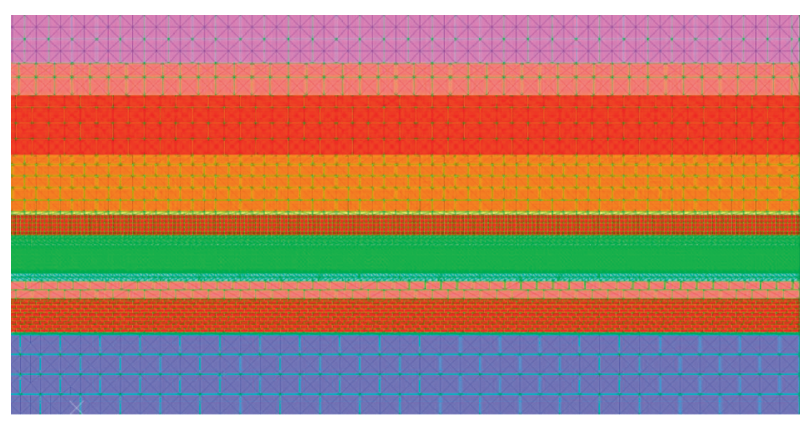

Figure 2: Numerical calculation model.

(1) When the working face advances $30 \mathrm{~m}$, it can be seen from Figure 3 that the immediate roof reaches the bearing limit and begins to collapse due to the excavation work. When the working face is pressed for the first time, the stress of the rock strata is released, and under the action of the dead weight, bending and sinking occur, and the main roof cracks begin to develop. A small amount of delamination fracture appears in the overlying strata and the disturbed coal seam 8\#. Broken fissures are formed at both ends of the working face and the open-off cut, and the delamination fracture in the overlying strata shows a parallel distribution. However, the evolution of the fissures has just begun, and the penetrating fissures have not yet occurred.

(2) When the working face advances $50 \mathrm{~m}$, it can be seen from Figure 4 that the collapse range of the immediate roof and the main roof increases obviously, and the immediate roof has collapsed, the main roof is fractured, and the working face is under periodic weighting. The upper coal seam $8 \#$ is deformed, and the delamination fracture continues to expand upward. The key layer fracture is increasing. The rock strata near the open-off cut side and the working face side are supported by the coal wall to form a shear 


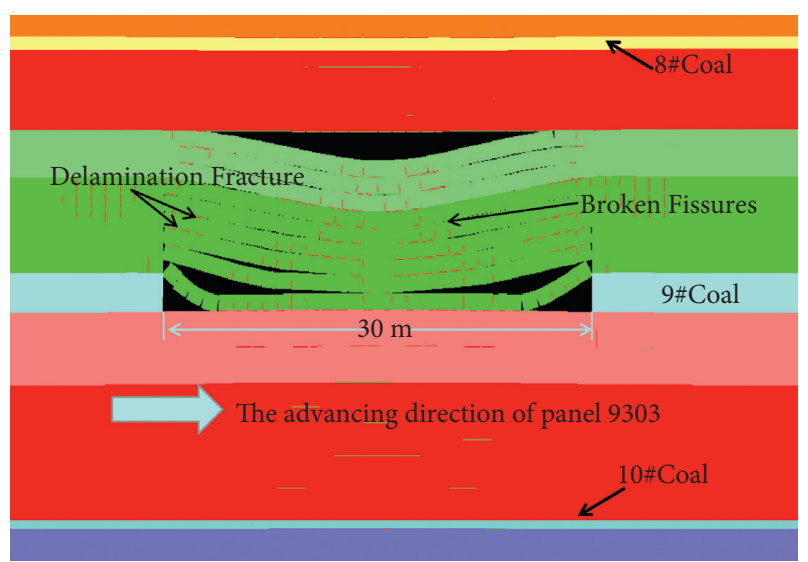

FIgURE 3: Evolution diagram of overlying strata fracture when working face advances to $30 \mathrm{~m}$.
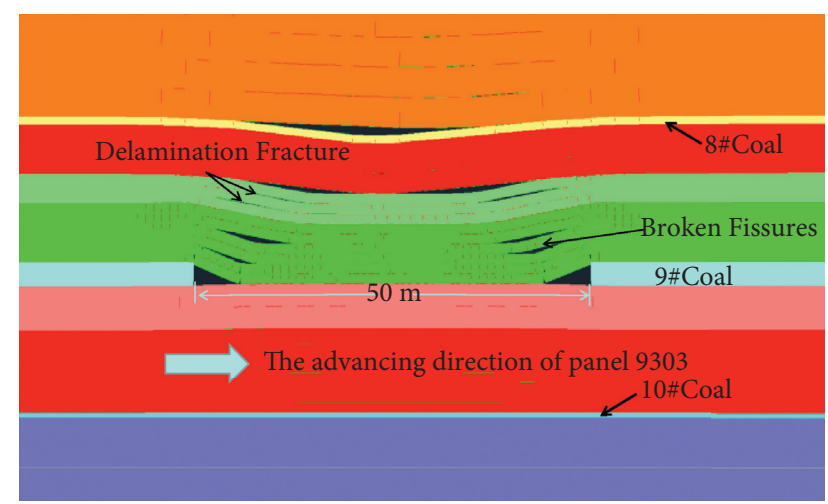

FIGURE 4: Evolution diagram of overlying strata fracture when working face advances to $50 \mathrm{~m}$.

effect on the upper part, forming a shear failure and then forming a broken fissure.

(3) When the working face advances $80 \mathrm{~m}$, it can be seen from Figure 5 that the roof fracture further expands to the overlying strata, and the overlying rock fracture area gradually expands. The delamination fracture and broken fissures continue to penetrate, and the key layer fracture develops well. The compaction area gradually forms in the middle of the overlying strata.

(4) When the working face advances $110 \mathrm{~m}$, it can be seen from Figure 6 that the delamination fracture begins to develop laterally, and the fracture in the middle of the goaf gradually disappears. The delamination fracture at the top of the fracture field is gradually replaced by the broken fracture at the bottom. With the continuous advancement of the working face, after $110 \mathrm{~m}$ mining in the working face, the fracture distribution form and scope of the overlying strata are gradually stable in the vertical direction. In the horizontal direction, the development of overlying rock fractures moves forward synchronously with the mining of working face, but does not continue to extend upward in the advancing direction. At this time, the fracture of overlying strata develops completely.

In summary, combined with the distribution of the fracture strengthening area and the compaction area of the overlying strata, the fracture strengthening area of the roof of the goaf is the main accumulation area of the pressure relief gas in the upper coal seam $8 \#$. The gas content is high and the concentration is large, which is the best choice for the hole arrangement layer of the drainage borehole. Through the simulation results when the working face is excavated to $110 \mathrm{~m}$, it can be obtained that the best fracture development of the overlying strata is with the height of $12.69 \mathrm{~m}$.

The above empirical formula calculation and numerical simulation results show that when the working face advances to $110 \mathrm{~m}$, the working face reaches full mining, the height of the "three zone" of the overlying strata is basically stable, and the maximum fracture zone is $12.69 \mathrm{~m}$. Therefore, the high directional long borehole should be arranged in the position of about $12 \mathrm{~m}$ of the coal seam roof.

3.3.3. Mining Fracture Height by Field Test. The borehole peeping method has the advantages of intuitive and convenient, which is widely used in coal mines to detect the geological structure of surrounding rock and the development of fractures [24, 25]. This borehole peeping adopts the intrinsically safe borehole peeper for mining. The minimum diameter of the peeping borehole is $25 \mathrm{~mm}$, and the length of the observable borehole is $30 \mathrm{~m}$. The working principle is to use the probe to convert light into electronic signals, and the signal is transmitted to the image receiver through the cable, so as to observe, record, and store the rock mass structure image in the borehole $[26,27]$.

This study mainly wants to obtain the fracture evolution height of roof strata affected by mining in panel 9303 during mining, so as to verify the rationality of numerical simulation and empirical formula calculation [28]. When arranging the peep boreholes test points, considering that a large amount of dust will be generated during the drilling construction, the test points are selected in the return airway. Combined with the actual position and advancing speed of the working face, two boreholes are constructed at $50 \mathrm{~m}$, $100 \mathrm{~m}$, and $150 \mathrm{~m}$ away from the open-off cut as the test points of peep boreholes. The layout of the observation borehole is shown in Figure 7, two boreholes are in one group, and the plane surface of each group is shown in Figure 8 . The borehole design of each group is the same. According to the actual situation of Anshun Mine, the vertical height of the final borehole position is determined to be $18 \mathrm{~m}$.

In order to analyze the development of fracture at different heights, so as to determine the fracture zone of the overlying strata on the roof, the borehole images of the same borehole with the advance of the working face in different periods and depths are intercepted, as shown in Figures 9 and 10. 


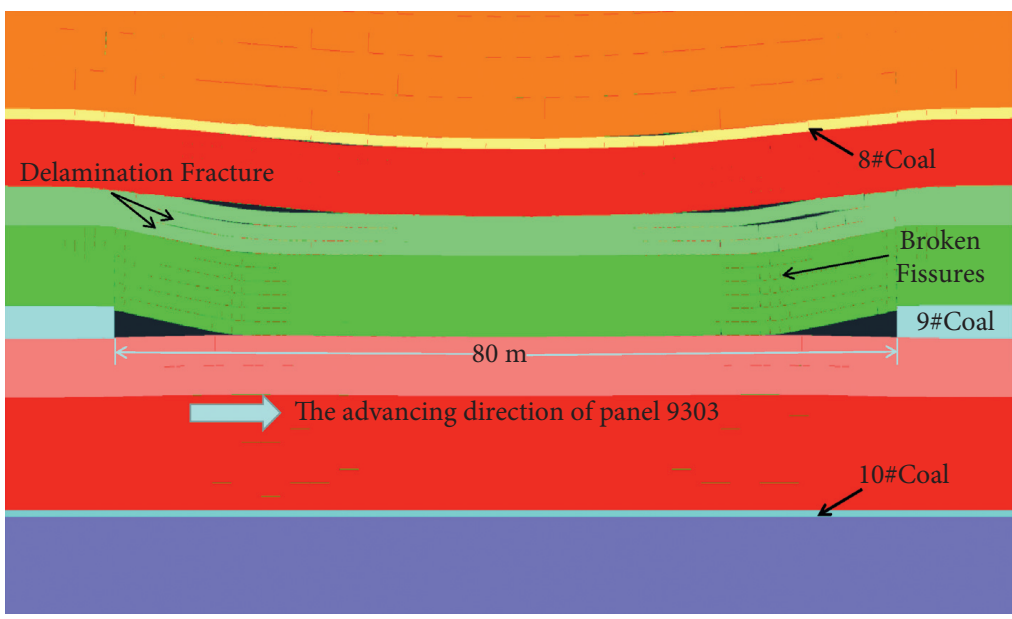

FIGURE 5: Evolution diagram of overlying strata fracture when working face advances to $80 \mathrm{~m}$.

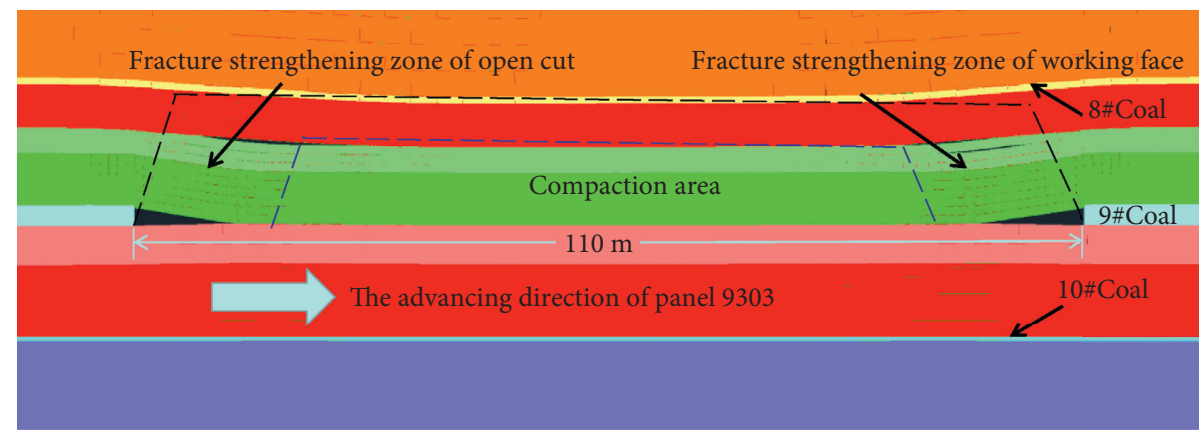

FIGURE 6: Distribution of fracture strengthening zone and compaction zone in overlying strata after stable fracture development.

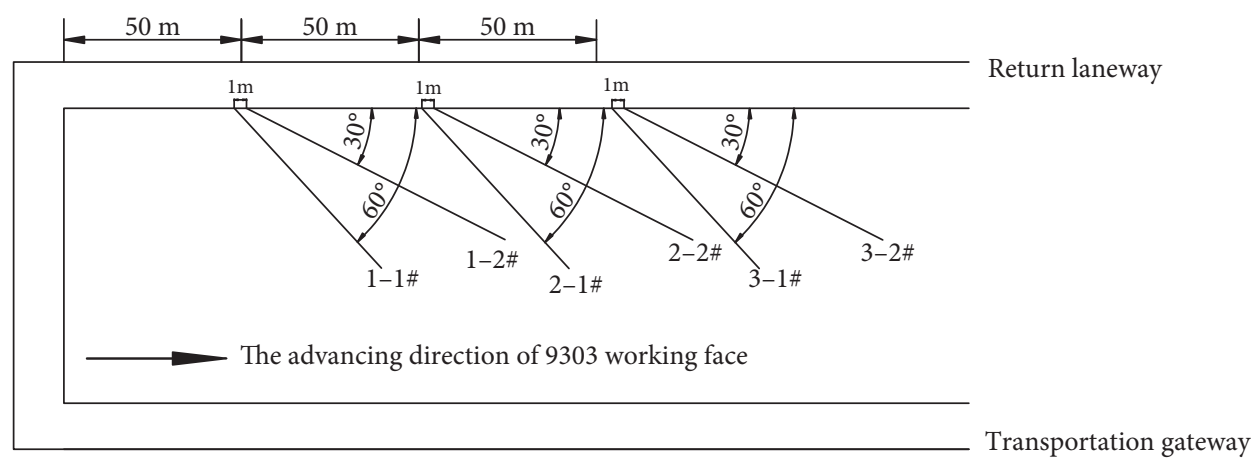

Figure 7: Peeping borehole layout schematic diagram.

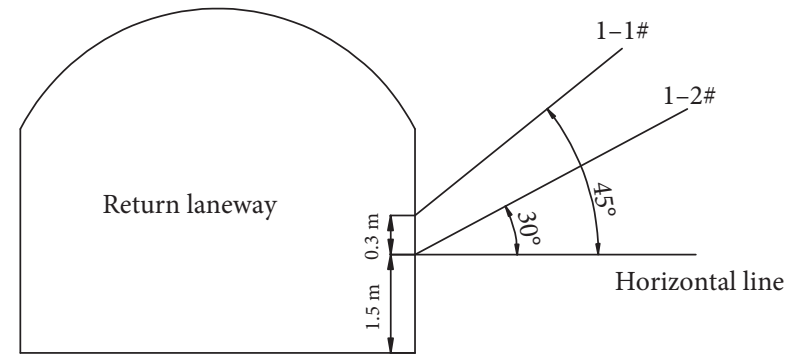

Figure 8: Peeping hole layout plane diagram.
From Figures 9 and 10, it can be seen that, from the opening up into the fracture zone, the fracture is more developed, the hole wall is broken until $10 \mathrm{~m}$, and then to the upper rock layer is more complete, but at the end hole height of $15 \mathrm{~m}$, there is a more broken section, which may be broken again after mining stress compression shear failure. The upper hole wall is basically intact, only a few places have slight damage. Therefore, the borehole observation results show that the height of water flowing fractured zone is not more than $15 \mathrm{~m}$. 


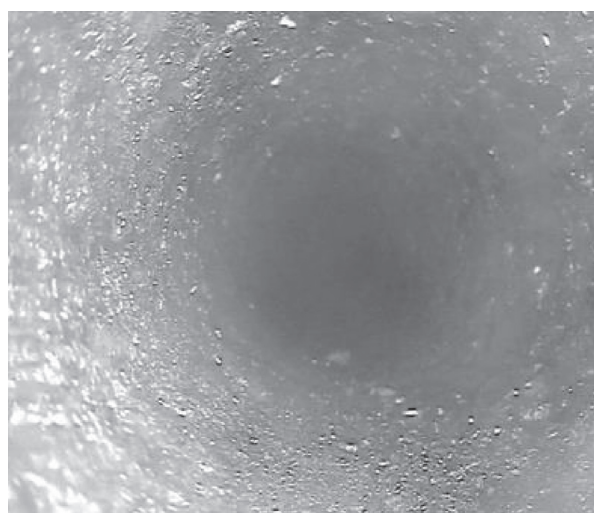

(a)

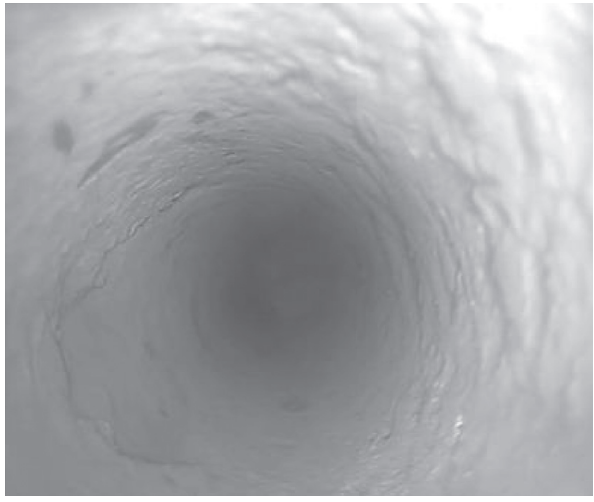

(c)

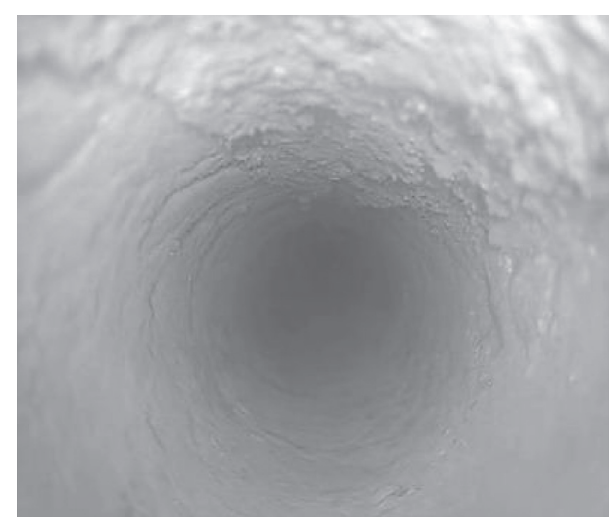

(b)

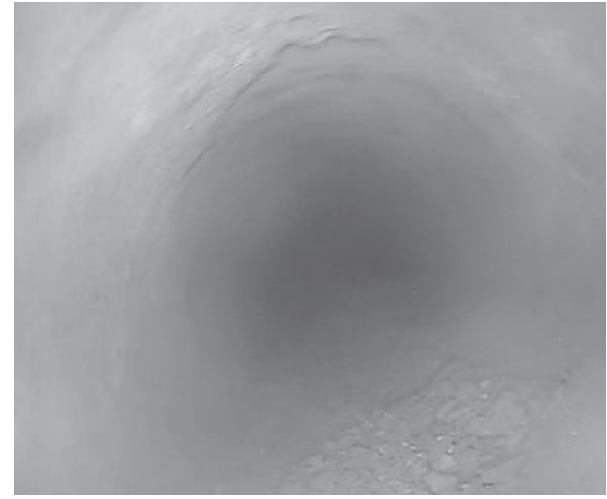

(d)

Figure 9: Drilling peep at different depths of 1-2\# observation hole when working face advances to $50 \mathrm{~m}$. (a) Final hole height $2 \mathrm{~m}$. (b) Final hole height $6 \mathrm{~m}$. (c) Final hole height $10 \mathrm{~m}$. (d) Final hole height $15 \mathrm{~m}$.

In summary, according to the same drilling hole in different hole depth peep, the analysis found that the fractures are mainly produced in the range of $6 \mathrm{~m}$ to $15 \mathrm{~m}$ above the roof, and the range changes with the advance of the working face. Through the analysis of images with different advancing distances and different borehole depths, it is found that when the working face advances to $100 \mathrm{~m}$, according to the peep images of 3-1\# and 3-2\# two boreholes, the fracture development situation shown by the images of $2-2 \#$ boreholes is similar. It can be concluded that the fracture development height gradually tends to be stable. Fracture zone range is within $6-15 \mathrm{~m}$.

\section{Parameter Design of Long Height Directional Drilling}

Comprehensively considering the results of empirical formula calculation and numerical simulation, and according to the field measurement verification, it can be seen that the hole arrangement layer of gas directional drilling in goaf of panel 9303 is selected at $12 \mathrm{~m}$ above coal seam 9\#. Due to the first use of directional drilling rig in this mine, in order to simplify the construction technology, the directional high drilling design adopts singlehole parallel arrangement and does not open branch holes.
In order to verify the above theoretical research results, the directional drilling rig drilling site is constructed in the lower side of tailentry 9303 (the drilling site position is shown in Figure 11). The drilling site specification is wide $\times$ deep $\times$ high $=10 \times 5 \times 3 \mathrm{~m}$. The opening position is located at $0.5-1 \mathrm{~m}$ of the coal seam roof and the opening spacing is $0.5-0.8 \mathrm{~m}$. The design inclination of the opening section is $10-14^{\circ}$. After drilling the sandstone on the roof of coal seam 9\#, the drilling direction is adjusted until the drilling reaches the predetermined position: $12 \mathrm{~m}$ above coal seam 9\# (as shown in Figure 12), and the final hole spacing is $7 \mathrm{~m}$. The parameters for five specific boreholes are as follows:

(1) Design parameters of 1-1 borehole: opening angle is $14^{\circ}$, opening azimuth is $331.9^{\circ}$, opening height is $0.3 \mathrm{~m}$ above coal seam roof, final hole height is $12 \mathrm{~m}$ above coal seam, and final design hole depth is $325 \mathrm{~m}$. The final hole is $8 \mathrm{~m}$ away from the roadway side.

(2) Design parameters of 1-2 borehole: opening angle is $14^{\circ}$, opening azimuth is $328.9^{\circ}$, opening height is $0.3 \mathrm{~m}$ above coal seam roof, final hole height is $12 \mathrm{~m}$ above coal seam, and final design hole depth is $335 \mathrm{~m}$. The final hole is $15 \mathrm{~m}$ away from the roadway side.

(3) Design parameters of 1-3 borehole: opening angle is $14^{\circ}$, opening azimuth is $325.9^{\circ}$, opening height is $0.3 \mathrm{~m}$ above coal seam roof, final hole height is $12 \mathrm{~m}$ 


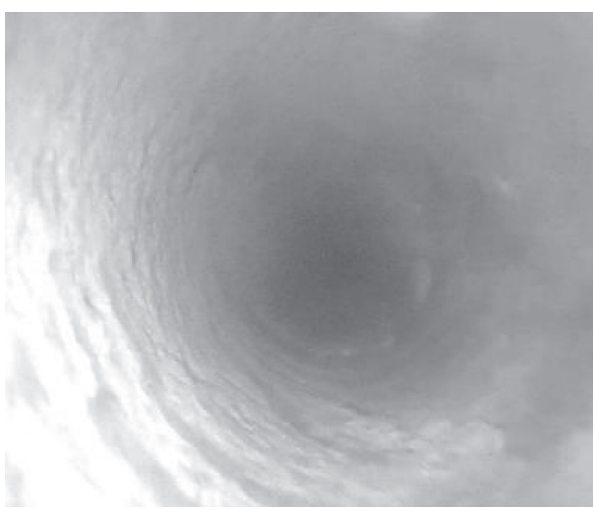

(a)

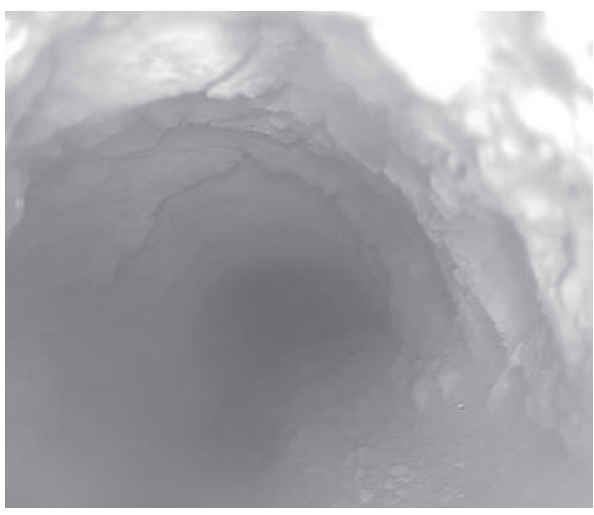

(c)

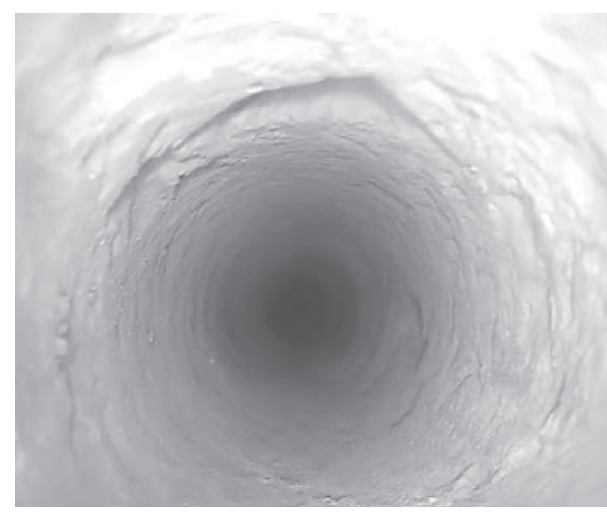

(b)

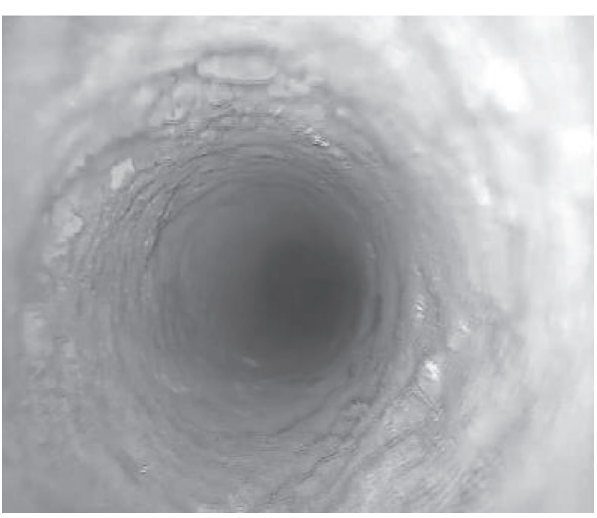

(d)

Figure 10: Drilling peep at different depths of 2-2\# observation hole when working face advances to $100 \mathrm{~m}$. (a) Final hole height $2 \mathrm{~m}$. (b) Final hole height $6 \mathrm{~m}$. (c) Final hole height $10 \mathrm{~m}$. (d) Final hole height $15 \mathrm{~m}$.

above coal seam, and final design hole depth is $335 \mathrm{~m}$. The final hole is $22 \mathrm{~m}$ away from the roadway side.

(4) Design parameters of 1-4 borehole: opening angle is $14^{\circ}$, opening azimuth is $322.9^{\circ}$, opening height is $0.3 \mathrm{~m}$ above coal seam roof, final hole height is $12 \mathrm{~m}$ above coal seam, and final design hole depth is $335 \mathrm{~m}$. The final hole is $29 \mathrm{~m}$ away from the roadway side.

(5) Design parameters of 1-5 borehole: opening angle is $14^{\circ}$, opening azimuth is $319.9^{\circ}$, opening height is $0.3 \mathrm{~m}$ above coal seam roof, final hole height is $12 \mathrm{~m}$ above coal seam, and final design hole depth is $335 \mathrm{~m}$. The final hole is $39 \mathrm{~m}$ away from the roadway side.

\section{Extraction Effect Analysis}

During the mining of panel 9303, the drainage effect of five high directional boreholes constructed by directional drilling field is significant. Gas drainage is shown in Figure 10. The extraction flow and gas concentration of five boreholes at different advancing distances were counted (as shown in Figure 13). When the mining face is $0 \sim 30 \mathrm{~m}$, the gas concentration of borehole extraction increases significantly, and the pure gas flow rate shows a rising trend to $5.5 \mathrm{~m}^{3} / \mathrm{min}$. At this stage, panel 9303 overlying strata has begun to form cracks due to the mining influence, and with the continuous development of cracks, drainage concentration and drainage gas flow are also rising. Subsequently, when the working face advances from $30 \mathrm{~m}$ to $110 \mathrm{~m}$, the concentration of gas drainage and the pure flow of gas drainage gradually increase. Since the overlying strata activities of the stope are continuously intensified, this causes disturbance to the upper coal seam $8 \#$ and makes the gas in the coal seam $8 \#$ continue to flow downward through the intertwined separated fractures and broken fractures. When the working face advances to $30 \mathrm{~m}$, the first weighting of the working face, the expansion deformation of the coal seam 8\#, and the gas pressure relief occur. When the working face advances to $50 \mathrm{~m}$, periodic weighting occurs. Before the periodic weighting, the borehole drainage flow and drainage concentration have a significant downward trend. After the periodic weighting, the borehole drainage concentration and drainage flow have a significant upward trend and then tend to be stable until the next periodic weighting. Subsequently, when the working face advances to $110 \mathrm{~m}$, the overall drainage effect of the borehole tends to be stable, entering the stage of efficient and lasting stable drainage. The drainage concentration reaches about $43 \%$, and the maximum pure gas flow rate reaches $8.5 \mathrm{~m}^{3} / \mathrm{min}$. 


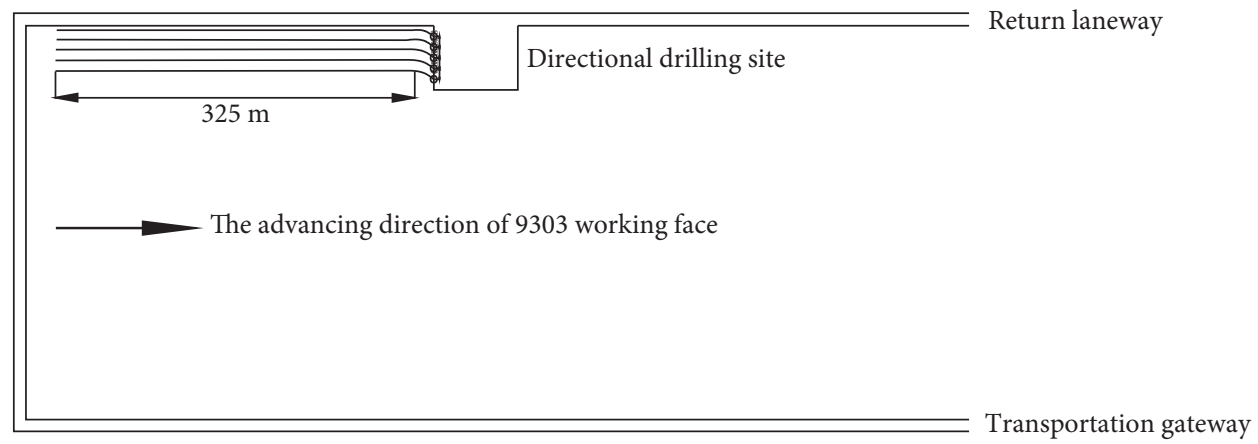

FIgURE 11: Indication diagram of directional long drilling field layout.

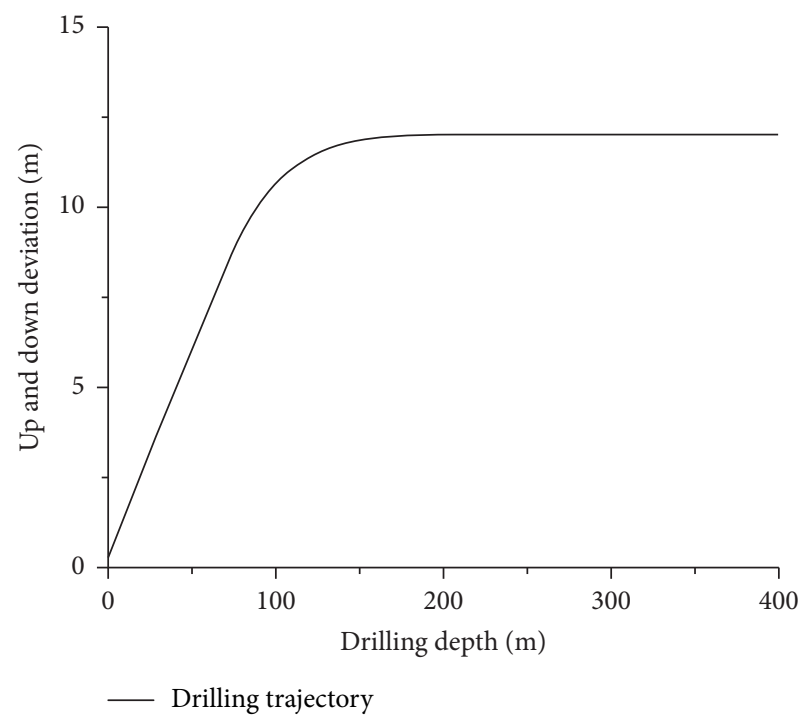

FIGURE 12: Design plane surface of directional drilling in return airway.

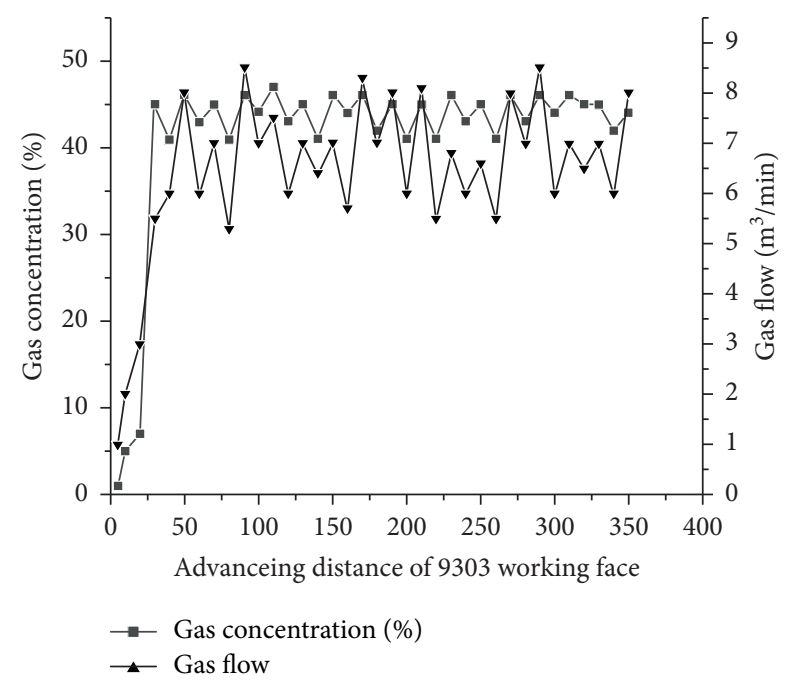

Figure 13: Gas extraction by directional long borehole.

During the mining period, the gas concentration in the return airway of the working face was $0.25 \%-0.4 \%$, and the gas concentration in the upper corner was also lower than $0.5 \%$, as shown in Figure 14. The high directional long

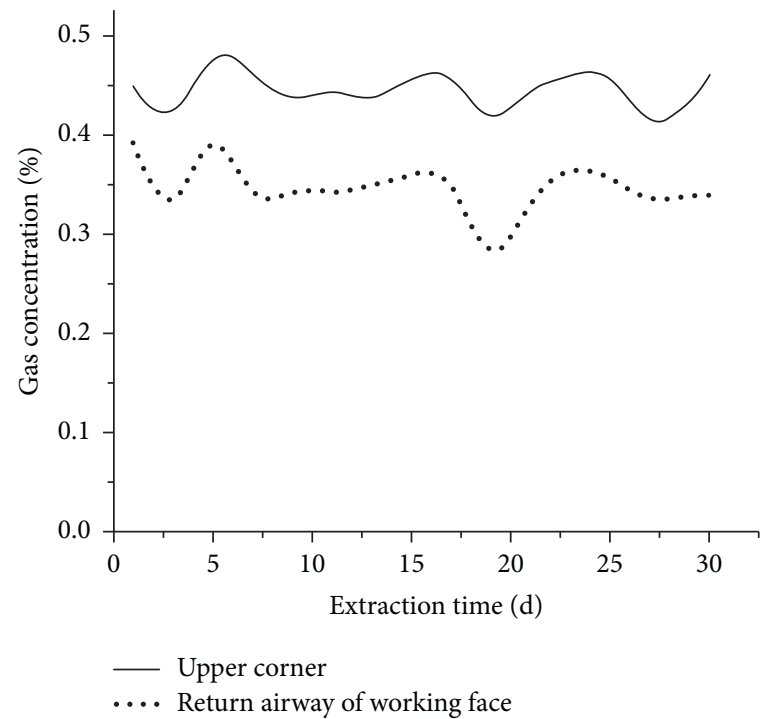

FIgURE 14: Gas condition of return airway and upper corner in working face.

borehole can effectively prevent the pressure relief gas of coal from 8 \# entering the return air flow through the fracture into the goaf, which leads to the problem of gas concentration overrun in the working face. At the same time, compared with the traditional high pumping roadway, the preparation time of the working face is shortened, the production cost is reduced, and the safe and efficient mining of the working face is ensured.

\section{Conclusions}

(1) Through theoretical analysis and numerical simulation under the real geological parameters condition, it is obtained that during the mining period of panel 9303 in Anshun Coal Mine, when the working face advances to $110 \mathrm{~m}$ position, the working face reaches fully mining, and the height range of "three zones" of overlying strata is basically stable. At this time, the development range of fracture zone is $6-12.69 \mathrm{~m}$, and this area is the best high drainage borehole final hole layer. The rationality of the development height of fracture zone obtained by theoretical analysis and numerical simulation is 
verified by the method of borehole peeping observation.

(2) By analyzing the field drainage effect of high directional long drilling, after the high directional long drilling in panel 9303 enters the stable and efficient extraction stage, the gas extraction rate is between $40 \%$ and $45 \%$, and the pure gas extraction amount is up to $8.5 \mathrm{~m}^{3} / \mathrm{min}$. The results show that the high directional long drilling has the advantages of gas concentration, large extraction amount, and stable flow, and the drilling drainage interception and extraction of adjacent layer gas is effective. It can provide reference for the arrangement of gas drainage boreholes in adjacent working faces and similar geological conditions.

\section{Data Availability}

The data used to support the findings of this study are included within the article.

\section{Conflicts of Interest}

The authors declare that they have no conflicts of interest regarding the publication of this study.

\section{Acknowledgments}

The authors acknowledge the financial support from the National Natural Science Foundation of China Youth Fund (no. 51904082), the National Natural Science Foundation of China Regional Fund (no. 52064005), the funding from Guizhou Science and Technology Plan Project (Qianke Science Foundation [2020] 1Y214), and the funding from Guizhou Science and Technology Plan Project (Qianke Science Support [2021] General 399).

\section{References}

[1] D.-Z. Kong, Z.-B. Cheng, and S.-S. Zheng, "Study on the failure mechanism and stability control measures in a largecutting-height coal mining face with a deep-buried seam," Bulletin of Engineering Geology and the Environment, vol. 78, no. 8, pp. 6143-6157, 2019.

[2] D. Z. Kong, S. J. Pu, Z. H. Cheng, G. Wu, and Y. Liu, "Coordinated deformation mechanism of the top coal and filling body of gob-side entry retaining in a fully mechanized caving face," International Journal of Geomechanics, vol. 21, no. 4, 2021.

[3] Y. Wang and J. K. Mang, "Study on gas drainage technology of roof directional long borehole replacing roadway with borehole," Mining Safety \& Environmental Protection, vol. 46, no. 5, pp. 95-98, 2019.

[4] C. Xu, F. Liu, and J. Fang, "Analysis on gas drainage technology and effect of long height directional drilling," Coal Engineering, vol. 49, no. 6, pp. 78-81, 2017.

[5] W. P. Cai, J. Liu, D. S. Sun et al., "Research and application of high level borehole gas drainage technology in roof strike," Journal of Safety Science and Technology, vol. 9, no. 12, pp. 35-38, 2013.
[6] Z. H. Cheng, Y. Lu, S. L. Su et al., "Study on high efficiency gas drainage mechanism of long height direction drilling in goaf roof," Coal Science and Technology, vol. 48, no. 2, pp. 136-142, 2020.

[7] Z. F. Li and X. M. Jin, "Numerical simulation of roof 'three zones' range division by UDEC," Mining Safety \& Environmental Protection, vol. 42, no. 4, pp. 21-24, 2015.

[8] D. Z. Kong, Y. Xiong, Z. B. Cheng, N. Wang, G. Wu, and Y. Liu, "Stability analysis of coal face based on coal facesupport-roof system in steeply inclined coal seam," Geomechanics and Engineering, vol. 25, no. 3, pp. 233-243, 2021.

[9] Z. J. Shi, Q. X. Li, and K. Yao, "Development path and key technology analysis of intelligent directional drilling in coal mine," Journal of China Coal Society, vol. 45, no. 6, pp. 2217-2224, 2020.

[10] B. Y. Yan, "Study on drilling technology of high directional long borehole," Coal Science and Technology, vol. 44, no. 4, pp. 55-58, 2016.

[11] N. P. Yao, J. Zhang, X. Jin, and H. Huang, "Status and development of directional drilling technology in coal mine," Procedia Engineering, vol. 73, pp. 289-298, 2014.

[12] Y. M. Li, "Study on gas control in upper corner based on long height directional drilling," Coal Science and Technology, vol. 46, no. 1, pp. 215-218, 2018.

[13] G. A. Zhu, B. W. Liu, L. M. Kou et al., "Simulation of working face mining process based on gob compaction effect," Journal of China University of Mining \& Technology, vol. 48, no. 4, pp. 775-783, 2019.

[14] J. Zhang and J. P. Wang, "High similarity simulation and empirical study of mining overburden three zones," Journal of Mining and Safety Engineering, vol. 31, no. 2, pp. 249-254, 2014.

[15] J. G. Zhao, "Construction technology and development trend of high - level directional drilling in coal seam roof," Coal Science and Technology, vol. 45, no. 6, pp. 137-141, 2017.

[16] G. H. Chen, Z. Y. Wei, D. F. Liang et al., "Practice of gas drainage by high directional long borehole in close distance coal seam group," Mining Safety \& Environmental Protection, vol. 46, no. 5, pp. 66-69, 2019.

[17] Q. Wu, S. Q. Zhao, S. N. Dong et al., Coal Mine Water Prevention Manual, China Coal Industry Publishing House, Beijing, China, 2013.

[18] F. H. Wang, "Determination method of height of gas caving zone and fracture zone in high borehole drainage," Coal Technology, no. 8, pp. 75-76, 2008.

[19] X. G. Zhu, H. C. Xia, and Z. C. Wang, "UDEC numerical simulation of overburden movement in coal seam mining," Journal of Liaoning Technical University, vol. 35, no. 12, pp. 1402-1410, 2016.

[20] J. C. Wang and Z. H. Wang, "Stress driving mechanism of crack propagation in top coal in fully mechanized caving mining," Journal of China Coal Society, vol. 43, no. 9, pp. 2376-2388, 2018.

[21] P. Yang, "Similar simulation study on mining fracture evolution law of overlying strata in mining field," Coal Science and Technology, vol. 42, no. 8, pp. 121-124, 2014.

[22] Y. Xue, J. Liu, P. G. Ranjith, X. Liang, and S. Wang, "Investigation of the influence of gas fracturing on fracturing characteristics of coal mass and gas extraction efficiency based on a multi-physical field model," Journal of Petroleum Science and Engineering, vol. 206, Article ID 109018, 2021.

[23] L. Zhu, F. Dang, Y. Xue, K. Jiao, and W. Ding, "Multivariate analysis of effects of microencapsulated phase change materials on mechanical behaviors in light-weight aggregate 
concrete," Journal of Building Engineering, vol. 42, Article ID 102783, 2021.

[24] Y. W. Peng, Q. X. Qi, Y. G. Wang et al., "Field measurement and application of coal mining fracture," Chinese Journal of Rock Mechanics and Engineering, vol. 29, no. S2, pp. 41884193, 2010.

[25] B. S. Nie, H. Zhang, S. J. Cui et al., "Method and application of extracting borehole information from forward - looking borehole peeping video," Journal of China Coal Society, vol. 41, no. 5, pp. 1316-1322, 2016.

[26] W. J. Yu and K. Li, "Deformation mechanism and control technology of surrounding rock in the deep-buried large-span chamber," Geofluids, vol. 2020, Article ID 8881319, 22 pages, 2020.

[27] H. Sun, G. C. Li, Y. H. Wei et al., "Application of geophysical prospecting combined with borehole peeping in rock mass structure detection," Safety In Coal Mines, vol. 45, no. 4, pp. 141-144, 2014.

[28] W. J. Yu, K. Li, Z. Liu, B. An, P. Wang, and H. Wu, "Mechanical characteristics and deformation control of surrounding rock in weakly cemented siltstone," Environmental Earth Sciences, vol. 80, p. 337, 2021. 